\title{
FILOSOFIA PARA A FORMAÇÃO DA CRIANÇA RESENHA
}

\author{
Lígia de Almeida Durante \\ Formada em Pedagogia pela UNESP de Araraquara
}

O livro em questão é de autoria de Paula Ramos de Oliveira, que desenvolveu o trabalho aqui analisado, a partir de sua tese de doutorado. Ele pode ser lido por qualquer pessoa que se interesse ou tenha curiosidade em relação ao assunto tratado, não é somente escrito para estudiosos da área.

No decorrer da leitura somos envolvidos pela linguagem de fácil compreensão que a autora utiliza, sem, contudo, fugir aos rigores acadêmicos. Podemos perceber que o assunto que dá nome ao livro (Filosofia Para A Formação Da Criança), é tratado com um total envolvimento (intelectual e psicológico) por parte da autora. Todo o referencial e bagagem teórica que são expostos no livro podem ser experienciados pelos relatos e descrições dos projetos de extensão $e$, ainda pela atuação individual da autora como professora de Filosofia inclusive no Ensino Fundamental.

A autora faz, neste livro, a crítica ao programa elaborado pelo filósofo estadunidense Matthew Lipman, de Filosofia Para Crianças. Paula Ramos parte de um estudo da realidade educacional brasileira, traçando um panorama histórico da situação da Filosofia como disciplina no currículo.

Posteriormente faz uma análise precisa da proposta Lipman (facilitando para quem nunca teve contato com esta proposta), contrapondo seus fundamentos teóricos e metodológicos, e o currículo por ele elaborado com o relato feito acima sobre a disciplina Filosofia.

A partir deste estudo propõe uma adaptação ou, até mesmo, uma transformação na proposta Lipman, que se adeque a nossa situação. Esta proposta é trabalhada em projetos de extensão coordenados por Paula e, como dito anteriormente, descritos no livro - terceiro capítulo.

Podemos notar uma forte influência dos estudos realizados pela Teoria Crítica na análise, feita pela autora, da proposta Lipman. Citando algumas vezes estudiosos desta corrente teórica, podemos perceber, na forma como narra e argumenta, uma grande similaridade de seu raciocínio com a forma de raciocínio da Teoria Crítica.

Este é um livro que abre portas para educadores que estão em busca de melhorias em sua formação e em sua forma de trabalhar e desmistifica alguns "achismos" em relação à Filosofia no Ensino Fundamental e Infantil. Fica evidente que a filosofia é possível com crianças pelo exercício do filosofar.

Além disso, o livro traz, dentro de si, um outro livro. Como um presente, a última parte do livro é composta de histórias filosóficas, criadas por integrantes do GEPFC 
(Grupo de Estudos e Pesquisa em Filosofia para Crianças) também coordenado por Paula Ramos.

Enfim, nos é disponibilizado o acesso a uma obra que tem toda uma argumentação acerca da pertinência do ensino de filosofia no início da escolaridade; mas, que ainda vai muito além disso: traz provas de que este ensino é possível e, conforme relatos e produções, os resultados para a educação das pessoas envolvidas foram muito edificantes.

OLIVEIRA, Paula Ramos. Filosofia Para a Formação da Criança. São Paulo: Pioneira Thomson Learning, 2004. 